\title{
Studi Kasus: Asuhan Keperawatan Jiwa Pada Tn T Dengan Halusinasi Pendengaran
}

\author{
Emmi Dorenci Tinambunan \\ Emmi.tinambunan@gmail.com
}

\section{BAB 1 \\ PENDAHULUAN}

\subsection{Latar Belakang}

Skizofrenia merupakan sekelompok reaksi psikotik yang memengaruhi berbagai area fungsi individu, termasuk berpikir, berkomunikasi, menerima, menginterpretasikan realitas, merasakan dan menunjukkan emosi (Pardede et al, 2016). Skizofrenia merupakan gangguan psikiatri yang menimbulkan disabilitas yang cukup luas, serta dicirikan oleh suatu siklus kekambuhan dan remisi. Sampai saat ini para ahli belum mendapatkan kesepakatan tentang definisi baku dari kekambuhan skizofrenia. Insiden kambuh pasien skizofrenia sangat tinggi, yaitu berkisar 60\%-75\% setelah suatu episode psikotik jika tidak diterapi. Pasien skizofrenia yang tidak teratur minum obat mengalami kekambuhan sebesar 74\%, di antaranya memerlukan rehospitalisasi sebasar 71\%. (Mubin \& Livana, 2019).

Skizofrenia merupakan gangguan mental berat dan kronis yang menyerang 20 juta orang di seluruh dunia (WHO, 2019). Di Indonesia berdasarkan hasil Riskesdas (2018) didapatkan estimasi prevalensi orang yang pernah menderita skizofrenia di Indonesia sebesar 1,8 per 1000 penduduk. Hasil survey awal yang dilakukan di poliklinik rawat jalan Rumah Sakit Jiwa Medan di temukan sebanyak 13.899 pasien yang rawat jalan dibawa oleh keluarganya untuk berobat. Prevalensi pasien berdasarkan jenis kelamin yaitu wanita berjumlah 4.499 orang dan laki - laki berjumlah 9.400 orang. Dari semua diagnosa pasien yang rawat jalan yang paling tinggi yaitu gangguan Skizofrenia yaitu sebesar 11.336 orang dari pasien yang berkunjung dibawa oleh keluarganya ke poli rawat jalan berjumlah 1158 pasien perbulan (Pardede, 2020). Penyakit skizofrenia lebih cenderung mengalami halusinasi. 
Halusinasi merupakan gangguan penerimaan panca indra tanpa stimulasi eksternal seperti halusinasi pendengaran, penglihatan, pengecapan, penciuman, dan perabaan (Wulandari, Siyamti \& Wulansari, 2020). Dampak yang dapat ditimbulkan oleh pasien yang mengalami halusinasi adalah kehilangan kontrol dirinya. Dimana pasien mengalami panik dan perilakunya dikendalikan oleh halusinasinya (Harkomah, 2019). Faktor-faktor yang mampu mempengaruhi kekambuhan penderita skizofrenia dengan halusinasi meliputi ekspresi emosi keluarga yang tinggi, pengetahuan keluarga yang kurang, ketersediaan pelayanan kesehatan, penghasilan keluarga dan kepatuhan minum obat pasien Skizofrenia (Pardede, 2020).

Proses keperawatan menjelaskan bagaimana perawat mengelolah asuhan pada individu, keluarga, kelompok, dan komunitas dengan pendekatan 3 penyelesaian masalah yang sistematis dalam pemberian asuhan keperawatan. Saat ini proses keperawatan di jelaskan sebagai proses siklik lima bagian yang meliputi pengkajian, diagnosis, perencanaan, pelaksanaan dan evaluasi (Utami,2021). Merawat pasien skizofrenia dengan masalah halusinasi dibutuhkan pengetahuan, keterampilan dan kesabaran serta dibutuhkan waktu yang lama akibat kronisnya penyakit ini (Pardede \& Laia, 2020).

Survei awal dilakukan di Yayasan Pemenang Jiwa Sumatra dengan jumlah pasien 70 orang tetapi yang menjadi subjek di dalam pembuatan askep ini berjumlah 1 orang dengan pasien masah halusinasi pendengaran atas nama inisial Tn $T$ penyebabnya Tn $\mathrm{T}$ sebagai subjek di karenakan pasien belum bisa mengatasi emosinya selain minum obat. Maka tujuan asuhan keperawatan yang akan di lakukan ialah untuk mengajarkan standar pelaksanaan masalah halusinasi pendengaran pada saat $\mathrm{Tn} \mathrm{T}$ mengalami halusinasinya.

\subsection{Tujuan}

Adapun tujuannya sebagai berikut : 


\subsubsection{Tujuan Umum}

Memberikan asuhan keperawatan pada Tn $\mathrm{T}$ dengan masalah Halusinasi Pendengaran di Yayasan Pemenang Jiwa Sumatera.

\subsubsection{Tujuan Khusus}

a. Melakukan Pengkajian pada klien Tn $\mathrm{T}$ dengan masalah Halusinasi Pendengaran di Yayasan Pemenang Jiwa Sumatera.

b. Merumuskan Diagnosa keperawatan pada $\mathrm{Tn} T$ dengan masalah Halusinasi Pendengaran di Yayasan Pemenang Jiwa Sumatera.

c. Menyusun Rencana Keperawatan pada Tn T dengan masalah Halusinasi Pendengaran di Yayasan Pemenang Jiwa Sumatera.

d. Melakukan Implementasikan pada Tn $\mathrm{T}$ dengan masalah Halusinasi Pendengaran di Yayasan Pemenang Jiwa Sumatera.

e. Melakukan Evaluasi tindakan keperawatan pada Tn T dengan masalah Halusinasi Pendengaran di Yayasan Pemenang Jiwa Sumatera.

\subsection{Manfaat}

\subsubsection{Bagi Klien}

Mendapatkan pengalaman serta dapat menerapkan apa yang telah dipelajari dalam penanganan kasus jiwa yang dialami dengan kasus nyata dalam pelaksanaan keperawatan, seperti cara untuk mengendalikan halusinasinya

\subsubsection{Bagi Perawat}

Asuhan keperawatan ini dapat dijadikan dasar informasi dan pertimbangan untuk menambah pengetahuan, keterampilan dan sikap dalam meningkatkan pelayanan perawatan pada Klien Gangguan Persepsi Sensori (Halusinasi Pendengaran) 


\subsubsection{Bagi Peneliti selanjutnya.}

Asuhan keperawatan ini dapat dijadikan dasar informasi dan pertimbangan peneliti selanjutnya untuk menambah pengetahuan tentang asuhan keperawatan gangguan persepsi sensori : halusinasi pendengaran 


\section{BAB 2 \\ TINJAUAN TEORITIS}

\subsection{Konsep Halusinasi}

\subsubsection{Defenisi}

Halusinasi adalah suatu keadaan dimana klien mengalami perubahan sensori persepsi yang disebabkan stimulus yang sebenarnya itu tidak ada (Hernadi, 2020). Halusinasi adalah persepsi klien terhadap lingkungan tanpa stimulus yang nyata, sehingga klien menginterpretasikan sesuatu yang tidak nyata tanpa stimulus atau rangsangan dari luar. Berdasarkan pengertian halusnasi itu dapat diartikan bahwa, halusinasi adalah gangguan respon yang diakibatkan oleh stimulus atau rangsangan yang membuat klien mempersepsikan sesuatu yang sebenarnya tidak ada (Hernadi, 2020).

Halusinasi merupakan hilangnya suatu kemampuan manusia dalam membedakan rangsangan internal (pikiran) dan rangsangan eksternal (dunia luar) sehingga tidak memungkinkan klien memberi persepsi atau pendapat tentang rangsangan yang nyata maupun lingkungan tanpa adanya objek (Wicakson, 2017). Halusinasi merupakan gangguan atau perubahan persepsi dimana pasien mempersepsikan sesuatu yang sebenarnya tidak terjadi. Suatu penerapan panca indra tanda ada rangsangan dari luar. Suatu penghayatan yang dialami suatu persepsi melaluipanca indra tanpa stimullus eksteren : persepsi palsu (Prabowo, 2014). 


\subsubsection{Klasifikasi Halusinasi}

Menurut Yusuf (2015) klasifikasi halusinasi dibagi menjadi 5 yaitu :

\begin{tabular}{|c|c|c|c|}
\hline No & $\begin{array}{c}\text { Jenis } \\
\text { halusinasi }\end{array}$ & Data Objektif & Data Subjektif \\
\hline 1 & $\begin{array}{l}\text { Halusinasi } \\
\text { Pendengaran }\end{array}$ & $\begin{array}{l}\text { 1. Bicara atau tertawa } \\
\text { sendiri tanpa lawan } \\
\text { bicara } \\
\text { 2. Marah-marah tanpa } \\
\text { sebab mencondongkan } \\
\text { telinga ke arah tertentu } \\
\text { 3. Menutup telinga }\end{array}$ & $\begin{array}{l}\text { 1. Mendengar suara atau } \\
\text { kegaduhan } \\
\text { 2. Mendengar suara yang } \\
\text { mengajak bercakap- } \\
\text { cakap } \\
\text { 3. Mendengar suara yang } \\
\text { menyuruh melakukan } \\
\text { sesuatu yang berbahaya }\end{array}$ \\
\hline 2 & $\begin{array}{l}\text { Halusinasi } \\
\text { penglihatan }\end{array}$ & $\begin{array}{l}\text { 1. Menunjuk-nunjuk ke } \\
\text { arah tertentu } \\
\text { 2. Ketakutan pada objek } \\
\text { yang tidak jelas }\end{array}$ & $\begin{array}{l}\text { 1. Melihat bayangan, sinar, } \\
\text { bentuk geometris, bentuk } \\
\text { kartun, melihat hantu } \\
\text { atau monster }\end{array}$ \\
\hline 3 & $\begin{array}{l}\text { Halusinasi } \\
\text { penghindu }\end{array}$ & $\begin{array}{l}\text { 1. Menghindu seperti } \\
\text { sedang membaui bau- } \\
\text { bauan tertentu } \\
\text { 2. Menutup hidung }\end{array}$ & $\begin{array}{l}\text { 1. Membaui bau-bauan } \\
\text { seperti bau darah, urine, } \\
\text { feses, } \\
\text { 2. kadang-kadang bau itu } \\
\text { menyenangkan }\end{array}$ \\
\hline 4 & $\begin{array}{l}\text { Halusinasi } \\
\text { pengecepan }\end{array}$ & $\begin{array}{l}\text { 1. Sering meludah } \\
\text { 2. Muntah }\end{array}$ & $\begin{array}{l}\text { 1. Merasakan rasa seperti } \\
\text { darah, urine, feses }\end{array}$ \\
\hline 5 & $\begin{array}{l}\text { Halusinasi } \\
\text { perabaan }\end{array}$ & $\begin{array}{l}\text { Menggaruk-garuk } \\
\text { permukaan kulit }\end{array}$ & $\begin{array}{l}\text { 1. Mengatakan ada } \\
\text { serangga di permukaan } \\
\text { kulit } \\
\text { 2. Merasa seperti tersengat } \\
\text { listrik }\end{array}$ \\
\hline
\end{tabular}




\subsubsection{Tanda dan Gejala}

Tanda dan gejala skizofrenia yang dapat terjadi pada klien dengan halusinasi adalah sebagai berikut: Terjadi peningkatan frekuensi pernapasan dan nadi, muka merah, sulit tidur serta ekspresi wajah tampak tegang dan berkeringat, kadang merasa ketakutan, mudah tersinggung, jengkel, merasa curiga, serta mudah marah, klien dengan halusinasi mengalami penurunan kemampuan secara kognitif, klien lebih banyak berbicara, senyum dan tertawa sendiri, klien juga mengatakan mendengar suara, melihat, menghirup, mengecap dan merasa sesuatu yang tidak nyata, gejala yang tampak meliputi sikap curiga dan bermusuhan sehingga klien dapat menarik diri dari lingkungannya (Pardede, Keliat \& Wardani, 2013).

Tanda dan gejala halusinasi dinilai dari hasil observasi terhadap pasien serta ungkapan pasien. Tanda dan gejala pasien halusinasi adalah sebagai berikut (Hafizuddin, 2021): :

a) Data Objektif

1) Bicara atau tertawa sendiri

2) Marah-marah tanpa sebab

3) Memalingkan muka ke arah telinga seperti mendengar sesuatu

4) Menutup telinga

5) Menunjuk-nunjuk ke arah tertentu

6) Ketakutan pada sesuatu yang tidak jelas

7) Mencium sesuatu seperti sedang membaui bau-bauan tertentu

8) Menutup hidung

9) Sering meludah

10) Muntah

11) Menggaruk-garuk permukaan kulit

b) Data subjektif

1) Mendengar suara-suara atau kegaduhan

2) Mendengar suara yang mengajak bercakap-cakap

3) Mendengar suara menyuruh melakukan sesuatu yang berbahaya 
4) Melihat bayangan, sinar, bentuk geometris, bentuk kartun, melihat hantu atau monster

5) Mencium bau-bauan seperti bau darah, urin, feses, kadang-kadang bau itu menyenangkan

6) Merasakan rasa seperti darah, urin atau feses

7) Merasa takut atau senang dengan halusinanya

8) Mengatakan sering mengikuti isi perintah halusinasi

\subsubsection{Etiologi}

Faktor predisposisi klien halusinasi menurut (Hafizuddin, 2021):

1. Faktor predisposisi

a. Faktor perkembangan Tugas perkembangan klien terganggu misalnya rendahnya kontrol dan kehangatan keluarga menyebabkan klien tidak mampu mandirisejak kecil, mudah frustasi, hilang percaya diri.

b. Faktor sosiokultural

Seseorang yang merasa tidak diterima dilingkungan sejak bayi akan merasa disingkirkan, kesepian, dan tidak percaya pada lingkungan

c. Faktor biologis

Mempunyai pengaruh terhadap terjadinya gangguan jiwa. Adanya stress yang berlebihan dialami seseorang maka didalam tubuh akan dihasilkan suatu zat yang dapat bersifat halusinogen neurokimia. Akibat stress berkepanjangan menyebabkan teraktivasinya neurotransmitter otak.

d. Faktor psikologis

Tipe kepribadian lemah dan tidak bertanggung jawab mudah terjerumus pada penyalahgunaan zat adikitif. Hal ini berpengaruh pada ketidakmampuan klien dalam mengambil keputusan yang tepat demi masa depannya, klien lebih memilih kesenangan sesaat dan lari dari alam nyata menuju alam khayal.

e. Faktor genetik dan pola asuh

Penelitian menunjukkan bahwa anak sehat yang diasuh oleh orang tua schizofrenia cenderung mengalami skizofrenia. Hasil studi menunjukkan bahwa faktor keluarga menunjukkan hubungan yang sangat berpengaruh 
pada penyakit ini.

\section{Faktor presipitasi}

Faktor presipitasi merupakan stimulus yang dipersepsikan oleh individu sebagai tantangan, ancaman, atau tuntutan yang memerlukan energi ekstra untuk menghadapinya. Seperti adanya rangsangan dari lingkungan, misalnya partisipasi klien dalam kelompok, terlalu lama tidak diajak komunikasi, objek yang ada di lingkungan dan juga suasana sepi atau terisolasi, sering menjadi pencetus terjadinya halusinasi. Hal tersebut dapat meningkatkan stress dan kecemasan yang merangsang tubuh mengeluarkan zat halusinogenik (Hafiszudiin,2021). Penyebab Halusinasi dapat dilihat dari lima dimensi yaitu :

1. Dimensi fisik

Halusinasi dapat ditimbulkan oleh beberapa kondisi fisik seperti kelelahan yang luar biasa, penggunaaan obat-obatan, demam hingga delirium, intoksikasi alkohol dan kesulitan untuk tidur dalam waktu yang lama.

\section{Dimensi Emosional}

Perasaan cemas yang berlebihan atas dasar problem yang tidak dapat diatasi merupakan penyebab halusinasi itu terjadi. Isi dari halusinasi dapat berupa perintah memaksa dan menakutkan. Klien tidak sanggup lagi menentang perintah tersebut hingga dengan kondisi tersebut klien berbuat sesuatu terhadap ketakutan tersebut.

\section{Dimensi Intelektual}

Dalam dimensi intelektual ini menerangkan bahwa individu dengan halusinasi akan memperlihatkan adanya penurunan fungsi ego. Pada awalnya halusinasi merupakan usaha dari ego sendiri untuk melawan impuls yang menekan, namun merupakan suatu hal yang menimbulkan kewaspadaan yang dapat mengambil seluruh perhatian klien dan tidak jarang akan mengontrol semua perilaku klien.

4. Dimensi Sosial

Klien mengalami interaksi sosial dalam fase awal dan comforting, klien meganggap bahwa hidup bersosialisasi di alam nyata sangat 
membahayakan. Klien asyik dengan Halusinasinya, seolah-olah ia merupakan tempat untuk memenuhi kebutuhan akan interaksi sosial, kontrol diri dan harga diri yang tidak didapatkan dakam dunia nyata.

\section{Dimensi Spiritual}

Secara sepiritual klien Halusinasi mulai dengan kehampaan hidup, rutinitas tidak bermakna, hilangnya aktifitas ibadah dan jarang berupaya secara sepiritual untuk menyucikan diri. Saat bangun tidur klien merasa hampa dan tidak jelas tujuan hidupnya. Individu sering memaki takdir tetapi lemah dalam upaya menjemput rezeki, menyalahkan lingkungan dan orang lain yang menyebabkan takdirnya memburuk. (Hafizuddin, 2021)

\subsubsection{Rentang Respon Halusinasi}

Rentang respon neurobiologi (Stuart 2013) :

Rentang Respon neurobiologis

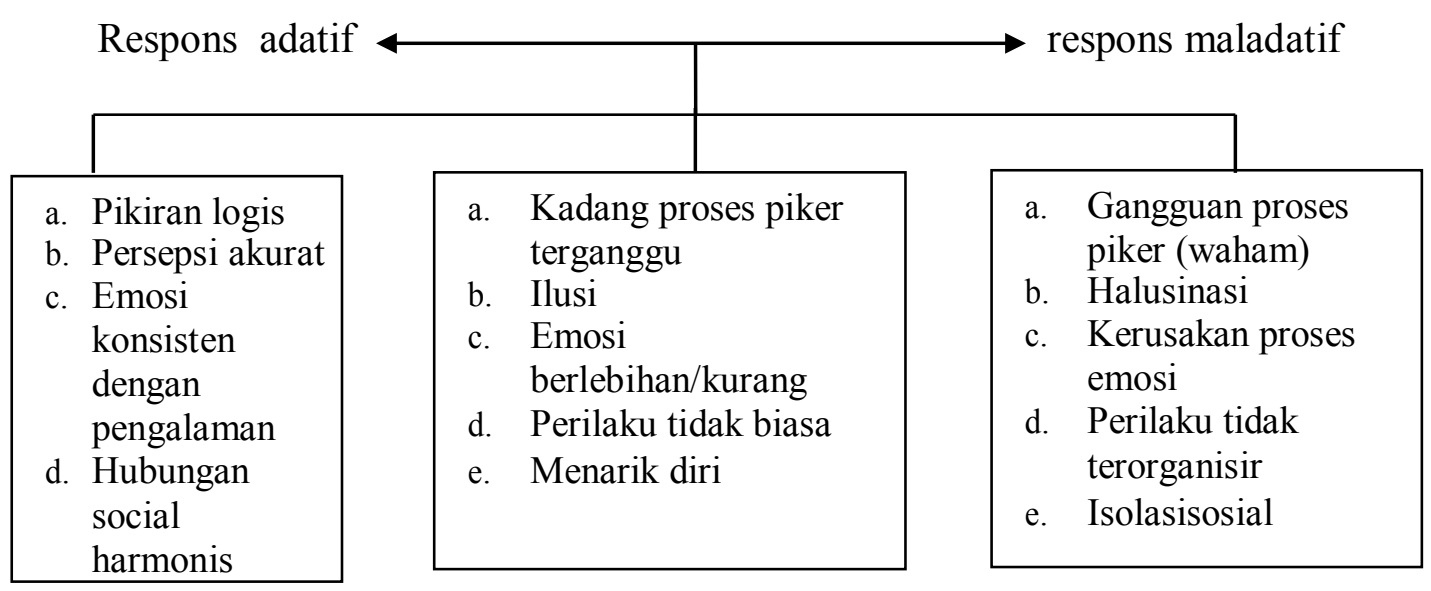

\section{Respon Adaptif}

Respon adaptif adalah respon yang dapat diterima norma-norma sosial budaya yang berlaku. Dengan kata lain individu tersebut dalam batas normal jika menghadapi suatu masalah akan dapat memecahkan masalah tersebut, respon adaptif:

a. Pikiran logis adalah pandangan yang mengarah pada kenyataan.

b. Persepsi akurat adalah pandangan yang tepat pada kenyataan. 
c. Emosi konsisten dengan pengalaman yaitu perasaan yang timbul dari pengalaman.

d. Perilaku sosial adalah sikap dan tingkah laku yang masih dalam batas kewajaran.

e. Hubungan sosial adalah proses suatu interaksi dengan orang lain dan lingkungan.

\section{Respon Psikososial}

Respon psikosial meliputi:

a. Proses pikir terganggu adalah proses pikir yang menimbulkan gangguan.

b. Ilusi adalah interpretasi atau penilaian yang salah tentang penerapan yang benar-benar terjadi (objek nyata) karena rangsangan panca indera.

c. Emosi berlebihan atau berkurang.

d. Perilaku tidak biasa adalah sikap dan tingkah laku yang melebihi batas kewajaran.

e. Menarik diri adalah percobaan untuk menghindar interaksi dengan orang lain.

\section{Respon Maladaptif}

Respon maladaptif adalah respon individu dalam menyelesaikan masalah yang menyimpang dari norma-norma sosial budaya dan lingkungan, adapun respon maladaptif meliputi:

a. Kelainan pikiran adalah keyakianan yang secara kokoh dipertahankan walaupun tidak diyakini oleh orang lain dan bertetangan dengan kenyataan sosial.

b. Halusinasi merupakan persepsi sensori yang salah atau persepsi eksternal yang tidak realita atau tidak ada.

c. Kerusakan proses emosi adalah perubahan sesuatu yang timbul dari hati.

d. Perilaku tidak terorganisir merupakan suatu yang tidak teratur.

e. Isolasi sosial adalah kondisi kesendirian yang dialami oleh individu dan diterima sebagai ketentuan oleh orang lain dan sebagai suatu kecelakaan yang negatif mengancam. 


\subsubsection{Fase Halusinasi}

Halusinasi terbagi atas beberapa fase (Oktiviani, 2020):

a. Fase Pertama / Sleep disorder

pada fase ini Klien merasa banyak masalah, ingin menghindar dari lingkungan, takut diketahui orang lain bahwa dirinyabanyak masalah. Masalah makin terasa sulit karna berbagai stressor terakumulasi, misalnya kekasih hamil, terlibat narkoba, dikhianati kekasih, masalah dikampus, drop out, dst. Masalah terasa menekan karena terakumulasi sedangkan support sistem kurang dan persepsi terhadap masalah sangat buruk. Sulit tidur berlangsung trus-menerus sehingga terbiasa menghayal. Klien menganggap lamunanlamunan awal tersebut sebagai pemecah masalah

b. Fase Kedua / Comforting

Klien mengalami emosi yang berlanjut seperti adanya perasaan cemas, kesepian, perasaan berdosa, ketakutan, dan mencoba memusatkan pemikiran pada timbulnya kecemasan. Ia beranggapan bahwa pengalaman pikiran dan sensorinya dapat dia kontrol bila kecemasannya diatur, dalam tahap ini ada kecenderungan klien merasa nyaman dengan halusinasinya

c. Fase Ketiga / Condemning

Pengalaman sensori klien menjadi sering datang dan mengalami bias. Klien mulai merasa tidak mampu lagi mengontrolnya dan mulai berupaya menjaga jarak antara dirinya dengan objek yang dipersepsikan klien mulai menarik diri dari orang lain, dengan intensitas waktu yang lama.

d. Fase Keempat / Controlling Severe Level of Anxiety

Klien mencoba melawan suara-suara atau sensori abnormal yang datang. Klien dapat merasakan kesepian bila halusinasinya berakhir. Dari sinilah dimulai fase gangguan psikotik.

e. Fase ke lima / Conquering Panic Level of Anxiety

Pengalaman sensorinya terganggu. Klien mulai terasa terancam dengan datangnya suara-suara terutama bila klien tidak dapat 


\subsubsection{Komplikasi}

Halusinasi dapat menjadi suatu alasan mengapa klien melakukan tindakan perilaku kekerasan karena suara-suara yang memberinya perintah sehingga rentan melakukan perilaku yang tidak adaptif. Perilaku kekerasan yang timbul pada klien skizofrenia diawali dengan adanya perasaan tidak berharga, takut dan ditolak oleh lingkungan sehingga individu akan menyingkir dari hubungan interpersonal dengan orang lain,komplikasi yang dapat terjadi pada klien dengan masalah utama gangguan sensori persepsi: halusinasi, antara lain: resiko prilaku kekerasan, harga diri rendah dan isolasi sosial (Keliat, 2014).

\subsection{Konsep Dasar Asuhan Keperawata}

\subsubsection{Pengkajian Keperawatan}

Menurut (Keliat, 2014). Bahwa faktor-faktor terjadinya halusinasi meliputi:

1. Faktor predisposisi

a. Faktor biologis

Pada keluarga yang melibatkan anak kembar dan anak yang diadopsimenunjukkan peran genetik pada schizophrenia.Kembar identik yang dibesarkan secara terpisah mempunyai angka kejadian Schizophrenia lebih tinggi dari pada saudara sekandung yang dibesarkan secara terpisah.

b. Faktor psikologis

Hubungan interpersonal yang tidak harmonis akan mengakibatkan stress dan kecemasan yang berakhir dengan gangguan orientasi realita.

c. Faktor sosial budaya

Stress yang menumpuk awitan schizophrenia dan gangguan psikotik lain, tetapi tidak diyakini sebagai penyebab utama gangguan. 
2. Faktor presipitasi

a. Biologis

Stressor biologis yang berhubungan dengan respon neurobiologis maladaptif adalah gangguan dalam komunikasi dan putaran umpan balik otak dan abnormalitas pada mekanisme pintu masuk dalam otak, yang

b. Lingkungan

Ambang toleransi terhadap stres yang ditentukan secara biologis berinteraksi dengan stresor lingkungan untuk menentukan terjadinya gangguan prilaku.

c. Stres sosial / budaya

Stres dan kecemasan akan meningkat apabila terjadi penurunan stabilitas keluarga, terpisahnya dengan orang terpenting atau disingkirkan dari kelompok.

d. Faktor psikologik

Intensitas kecemasan yang ekstrem dan memanjang disertai terbatasnya kemampuan mengatasi masalah dapat menimbulkan perkembangan gangguan sensori persepsi halusinasi.

e. Mekanisme koping

Perilaku yang mewakili upaya untuk melindungi pasien dari pengalaman yang menakutkan berhubungan dengan respons neurobiologis maladaptif meliputi : regresi, berhunbungan dengan masalah proses informasi dan upaya untuk mengatasi ansietas, yang menyisakan sedikit energi untuk aktivitas sehari-hari. Proyeksi, sebagai upaya untuk menejlaskan kerancuan persepsi dan menarik diri.

f. Sumber koping

Sumber koping individual harus dikaji dengan pemahaman tentang pengaruh gangguan otak pada perilaku. Orang tua harus secara aktif mendidik anak-anak dan dewasa muda tentang keterampilan koping karena mereka biasanya tidak hanya belajar dari pengamatan. Disumber keluarga dapat pengetahuan tentang penyakit, finensial yang cukup, faktor ketersediaan waktu dan tenaga serta kemampuan untuk memberikan dukungan secara berkesinambungan. 


\section{g. Perilaku halusinasi}

Batasan karakteristik halusinasi yaitu bicara teratawa sendiri, bersikap seperti memdengar sesuatu, berhenti bicara ditengah - tengah kalimat untuk mendengar sesuatu, disorientasi, pembicaraan kacau dan merusak diri sendiri, orang lain serta lingkungan.

\subsubsection{Diagnosa Keperawatan}

Menurut NANDA 2015-2017 yakni gangguan persepsi. Dengan faktor berhubungan dan batasan karakteristik disesuaikan dengan keadaan yang ditemukan pada tiap-tiap partisipan. Topik yang diteliti yakni kemampuan mengontrol halusinasi dengar (Aji, 2019).

\subsubsection{Perencanaan Keperawatan}

Rencana tindakan pada keluarga (Husein,\& Arifin,2011) adalah ;

1. Diskusikan masalah yang dihadap keluarga dalam merawat pasien

2. Berikan penjelasan meliputi : pengertian halusinasi, proseterjadinya halusinasi, jenis halusinasi yang dialami, tanda dan gejala halusinasi, proses terjadinya halusinasi.

3. Jelaskan dan latih cara merawat anggota keluarga yang mengalami halusinasi : menghardik, minum obat, bercakap- cakap, melakukan aktivitas.

4. Diskusikan cara menciptakan lingkungan yang dapat mencegah terjadinya halusinasi.

5. Diskusikan tanda dan gejala kekambuhan

Diskusikan pemanfaatan fasilitas pelayanan kesehatan terdekat untuk follow up anggota keluarga dengan halusinasi.

\subsubsection{Implementasi}

Implementasi disesuaikan dengan rencana tindakan keperawatan. Pada situasi nyata sering pelaksanaan jauh berbeda dengan rencana, hal ini terjadi karena perawat belum terbiasa menggunakan rencana tertulis dalam melaksanakan 
tindakan keperawatan. Sebelum melaksanakan tindakan keperawatan yang sudah direncanakan, perawat perlu memvalidasi dengan singkat apakah rencana tindakan masih sesuai dan dibutuhkan klien sesuai dengan kondisinya (here and now). Perawat juga menilai diri sendiri, apakah kemampuan interpersonal, intelektual, tekhnikal sesuai dengan tindakan yang akan dilaksanakan, dinilai kembali apakah aman bagi klien. Setelah semuanya tidak ada hambatan maka tindakan keperawatan boleh dilaksanakan.( Zelika 2015)

Adapun pelaksanaan tindakan keperawatan jiwa dilakukan berdasarkan Strategi Pelaksanaan (SP) yang sesuai dengan masing- masing masalah utama. Pada masalah gangguan sensori persepsi: halusinasi pendengaran, terdapat 2 jenis SP, yaitu SP Klien dan SP Keluarga.SP klien terbagi menjadi SP 1 (membina hubungan saling percaya, mengidentifikasi halusinasi "jenis, isi, waktu, frekuensi, situasi, perasaan dan respon halusinasi”, mengajarkan cara menghardik, memasukan cara menghardik ke dalam jadwal; SP 2 (mengevaluasi SP 1, mengajarkan cara minum obat secara teratur, memasukan ke dalam jadwal); SP 3 (mengevaluasi SP 1 dan SP 2, menganjurkan klien untuk mencari teman bicara); SP 4 (mengevaluasi SP 1, SP 2, dan SP 3, melakukan kegiatan terjadwal). SP keluarga terbagi menjadi SP 1 (membina hubungan saling percaya, mendiskusikan masalah yang dihadapi keluarga dalam merawat pasien, menjelaskan pengertian, tanda dan gejala helusinasi, jenis halusinasi yang dialami klien beserta proses terjadinya, menjelaskan cara merawat pasien halusinasi); SP 2 (melatih keluarga mempraktekan cara merawat pasien dengan halusinasi, melatih keluarga melakukan cara merawat langsung kepada pasien halusinasi); SP 3 (membantu keluarga membuat jadwal aktivitas di rumah termasuk minum obat (discharge planing), menjelaskan follow up pasien setelah pulang)

Pada saat akan dilaksanakan tindakan keperawatan maka kontrak dengan klien dilaksanakan dengan menjelaskan apa yang akan dikerjakan dan peran serta klien yang diharapkan, dokumentasikan semua tindakan yang telah 
dilaksanakan serta respon klien.

\subsubsection{Evaluasi Keperawatan}

Evaluasi adalah proses hasil atau sumatif dilakukan dengan membandingkan respon klien pada tujuan umum dan tujuan khusus yang telah ditentukan.halusinasi pendengaran tidak terjadi perilaku kekerasan, klien dapat membina hubungan saling percaya, klien dapat mengenal halusinasinya, klien dapat mengontrol halusinasi dengar dari jangka waktu 4x24 jam didapatkan data subjektif keluarga menyatakan senang karena sudah diajarkan teknik mengontrol halusinasi, keluarga menyatakan pasien mampu melakukan beberapa teknik mengontrol halusinasi. Data objektif pasien tampak berbicara sendiri saat halusinasi itu datang, pasien dapat berbincang-bincang dengan orang lain, pasien mampu melakukan aktivitas terjadwal, dan minum obat secara teratur. (Aji, 2019) 


\section{BAB 3 \\ TINJAUAN KASUS}

\subsection{Identitas Klien}

$\begin{array}{lll}\text { Inisial } & : & \text { Tn T } \\ \text { Jenis kelamin } & : & \text { Laki-laki } \\ \text { Umur } & : & 36 \text { Tahun } \\ \text { Agama } & : & \text { kristen } \\ \text { Status } & : & \text { Belum Menikah } \\ \text { Tanggal pengkajian } & : & 19 \text { februari } 2021 \\ \text { Informent } & : & \text { Status klien dan komunikasi dengan klien. }\end{array}$

\subsection{Alasan Masuk Rumah Sakit}

Alasan klien masuk di yayasan pemenang jiwa adalah karena klien sering marah-marah, dan Mendengar Suara-suara yang menyuruhnya untuk memukul dan marah-marah pada setiap orang yang dijumpainya.

\subsection{Faktor Predisposisi}

Dirumah klien tidak rutin minum obat, tidak mau kontrol ke RSJ sehingga timbul gejalagejala seperti diatas, klien sering marah-marah dan memukul orangtua nya hingga mengalami cidera,hingga akhirnya keluarga membawa klien ke Yayasan pemenang jiwa Sumatera Utara pada tanggal 24 Maret 2018. Keluarga klien tidak ada yang pernah mengalami gangguan jiwa.

Masalah Keperawatan:Halusinasi Pendengaran

Regiment individu Terapeutikinefektif

\subsection{Fisik}

Klien memiliki keluhan fisik, gatal-gatal dibagian kaki dan tangan, sakit kepala, dan saat dilakukan pemeriksaan tanda-tanda vital, didapatkan hasil TD : 110/80 $\mathrm{mmHg} ; \mathrm{N}: 80 \mathrm{x} / \mathrm{i}$; $\mathrm{S}: 36,5^{\circ} \mathrm{C} ; \mathrm{P}: 22 \mathrm{x} / \mathrm{i}$. Klien memiliki tinggi badan $168 \mathrm{~cm}$ dan berat badan $65 \mathrm{Kg}$. 


\subsection{Psikososial}

\subsubsection{Genogram}

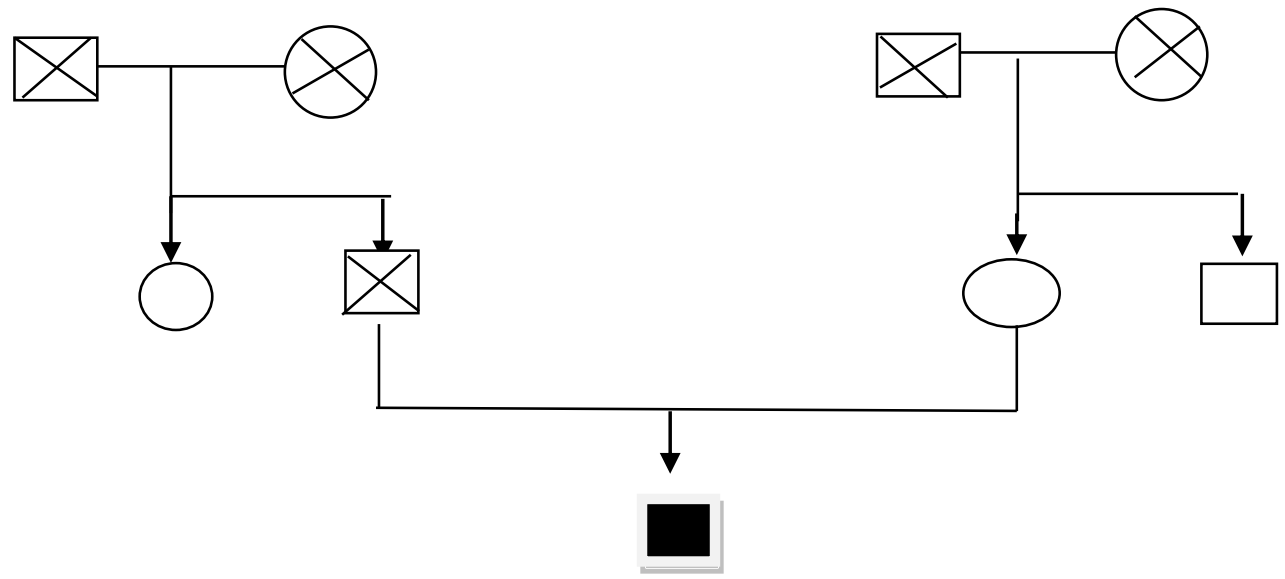

Penjelasan :

Klien merupakan anak Tunggal. Klien belum pernah menikah.

Keterangan :

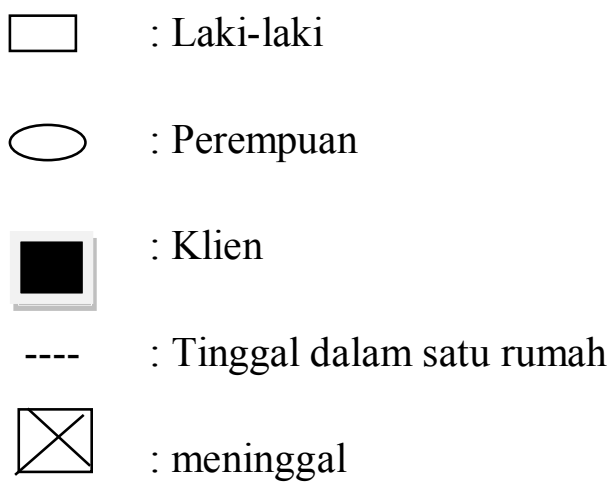

\subsubsection{Konsep diri}

a. Gambaran diri : Klien menyukai seluruh tubuhnya dan tidak ada yang cacat

b. Identitas : Klien anak Tunggal, klien hanya lulusan Smp yang saat ini tidak memiliki pekerjaan

c. Peran : Klien berperan sebagai anak dikeluarga, klien tinggal bersama Orang tua nya

d. Ideal diri $\quad$ : Klien merasa malu karena klien dirawat di RSJ dan ingin cepat pulang ke rumah. 
e. Harga diri : Klien mengatakan merasa malu berada di rumah sakit jiwa dan merasa bosan.

Masalah keperawatan:Gangguan konsep diri : harga diri rendah

\subsubsection{Hubungan sosial}

Klien mengatakan mempunyai hambatan dalam berhubungan dengan orang lain karena klien sulit bergaul dan selalu ingin menyendiri.

Masalah keperawatan:Isolasi Sosial : Menarik diri

\subsubsection{Spiritual}

a. Nilai dan Keyakinan : Klien beragama Kristen dan yakin dengan agamanya.

b. Kegiatan Ibadah : Klien ikut melakukan ibadah selama dirawat.

\subsubsection{Status Mental}

1. Penampilan

Klien berpenampilan bersih, dan rapi

2. Pembicaraan

Klien masih mampu menjawab pertanyaan perawat dengan lambat namun dapat dipahami

3. Aktivitas Motorik

Klien terlihat gelisah

4. Suasana perasaan

Klien merasa bosan selama di rawat di Pemenang Jiwa.

5. Afek

Afek klien labil, mudah emosi, mudah marah jika disuruh bekerja.

6. Interaksi selama wawancara

PKlien kooperatif, jika berbicara klien kadang-kadang memalingkan wajah dan tidak nyambung.

7. Persepsi

Klien mengatakan bahwa ada suara-suara yang menyuruh untuk marah-marah dan memukul orang.

8. Proses Pikir

Klien mampu menjawab apa yang ditanya dengan baik.

9. Isi pikir 
Klien dapat mengontrol isi pikirnya,klien tidak mengalami gangguan isi pikir dan tidak ada waham. Klien tidak mengalami fobia, obsesi ataupun depersonalisasi.

10. Tingkat kesadaran

Klien tidak mengalami gangguan orientasi, klien mengenali waktu, orang dan tempat.

\section{Memori}

Klien mampu menceritakan kejadian di masa lalu dan yang baru terjadi.

12. Tingkat konsentrasi berhitung

Klien mampu berkonsentrasi dalam perhitungan sederhana tanpa bantuan orang lain.

13. Kemampuan penilaian

Klien dapat membedakan hal yang baik dan yang buruk.

14. Daya tilik diri

Klien tidak mengingkari penyakit yang diderita, klien mengetahui bahwa dia sedang sakit dan dirawat di rumah sakit jiwa.

\subsection{Mekanisme Koping}

Klien mengalami mekanisme koping adaptif yaitu klien dapat berbicara baik dengan orang lain.

\subsection{Masalah Psikososial dan Lingkungan}

Klien mengatakan sulit berteman dengan orang lain karena klien selalu ingin menyendiri.

\subsection{Pengetahuan Kurang Tentang Gangguan Jiwa}

Klien mengetahui tentang gangguan jiwa yang di alaminya dan obat yang dikonsumsinya.

\subsection{Aspek Medik}

Diagnosa medis : Skizofrenia Paranoid

Terapi medis yang diberikan:

a. Resperidon tablet $2 \mathrm{mg} 2 \mathrm{x} 1$

b. Chlozapine tablet $25 \mathrm{mg} 1 \mathrm{x} 1$ 


\begin{tabular}{|c|c|c|}
\hline No & Analisa Data & Masalah keperawatan \\
\hline 1 & \begin{tabular}{|l} 
DS : \\
- Keluarga mengatakan klien \\
sering berbicara sendiri dan \\
tertawa sendiri \\
- Klien sering mendengar suara- \\
suara yang menyuruhnya \\
untuk pergi jalan-jalan \\
- Klien terkadang tampak \\
senang ketika halusinasinya \\
datang \\
- Klien sering mendengar suara- \\
suara ketika pagi hari, dan \\
sebelum tidur malam klien \\
sering berbicara sendiri \\
terlebih dahulu \\
DO : \\
- Klien tampak berbicara sendiri \\
- Klien berbicara sendiri seperti \\
ada dunianya \\
- Klien berbicara ngawur \\
Klien juga sering senyum- \\
senyum sendiri
\end{tabular} & $\begin{array}{l}\text { Gangguan persepsi sensori } \\
\text { Halusinasi pendengaran }\end{array}$ \\
\hline
\end{tabular}




\begin{tabular}{|c|c|c|}
\hline 2 & $\begin{array}{l}\text { DS : Klien mengatakan mendengar } \\
\text { suara suara yang menyuruhnya } \\
\text { memukul orang lain } \\
\text { DO : Klien tampak memandang } \\
\text { orang lain dengan tatapan } \\
\text { bermusuhan dan gelisah }\end{array}$ & Resiko Perilaku Kekerasan \\
\hline $\mathrm{a}$ & \begin{tabular}{|ll} 
Ds : & \\
& keluarga \\
& mengatakan pasien suka \\
& mengurungdiri. \\
- & Pasien mengatakan tidak \\
& mau berhubungan dengan \\
& orang lain. \\
Do: & \\
- & Pasien tampak menunduk \\
- & Pasien menarik diri tidak \\
& mau bergaul \\
- & Pasien tampak menunduk
\end{tabular} & Isolasi Sosial : Menarik Diri \\
\hline
\end{tabular}

\subsection{Masalah Keperawatan}

1. Gangguan Persepsi Sensori: Halusinasi Pendengaran

2. Isolasi Sosial: Menarik Diri

3. Risiko Perilaku Kekerasan

\subsection{Pohon Masalah}

Resiko Perilaku Kekerasan

Gangguan persepsi sensori : Halusinasi Pendengaran

$$
\uparrow
$$

Isolasi Sosial: Menarik diri 


\subsection{Prioritas Diagnosa Keperawatan}

- Gangguan persepsi Sensorik : Halusinasi pendengaran

\subsection{Intervensi Keperawatan}

\begin{tabular}{|c|c|c|}
\hline No & Analisa Data & Masalah keperawatan \\
\hline 1 & $\begin{array}{ll}\text { Gangguan Persepsi } & \text { Sensori } \\
\text { Halusinasi Pendengaran } & \end{array}$ & $\begin{array}{l}\text { SP 1: } \\
\text { 1. Mengidentifikasi r risi, } \\
\quad \text { frekuensi, waktu terjadi, } \\
\quad \text { situasi pencetus, perasaan } \\
\quad \text { daan respon halusinasi } \\
\text { 2. Mengontrol halusinasi dengan } \\
\quad \text { menghardik } \\
\text { SP 2: } \\
\text { Mengontrol halusinasi dengan } \\
\text { minum obat secara teratur } \\
\text { SP 3: } \\
\text { Mengontrol halusinasi dengan } \\
\text { bercakap-cakap dengan orang lain } \\
\text { SP 4: } \\
\text { Mengontrol halusinasi dengan } \\
\text { melakukan kegiatan terjadwal }\end{array}$ \\
\hline
\end{tabular}




\begin{tabular}{|c|c|c|}
\hline 2 & Perilaku Kekerasan & $\begin{array}{l}\text { Sp1: } \\
\text { 1. } \text { Identifikasi penyebab, frekuensi } \\
\text { perilaku kekerasan } \\
\text { 2. } \text { Mengontrol perilaku kekerasan } \\
\text { dengan Tarik nafas dalam dan } \\
\text { pukul kasur/bantal } \\
\text { Sp2: } \\
\text { Kontrol perilaku kekerasan } \\
\text { dengan minum obat secara } \\
\text { teratur } \\
\text { Sp 3: } \\
\text { Control perilaku kekerasan } \\
\text { dengan berbicara baik-baik } \\
\text { Sp 4: } \\
\text { Spiritual }\end{array}$ \\
\hline 3. & Isolasi Sosial : Menarik Diri & $\begin{array}{l}\text { SP 1 : } \\
\text { Menjelaskan keuntungan dan } \\
\text { kerugian mempunyai teman } \\
\text { SP 2 : } \\
\text { Melatih klen berkenalam dengan } 2 \\
\text { orang atau lebih } \\
\text { SP 3 : } \\
\text { Melatih bercakap cakap sembil } \\
\text { melakukan kegiatan harian }\end{array}$ \\
\hline
\end{tabular}




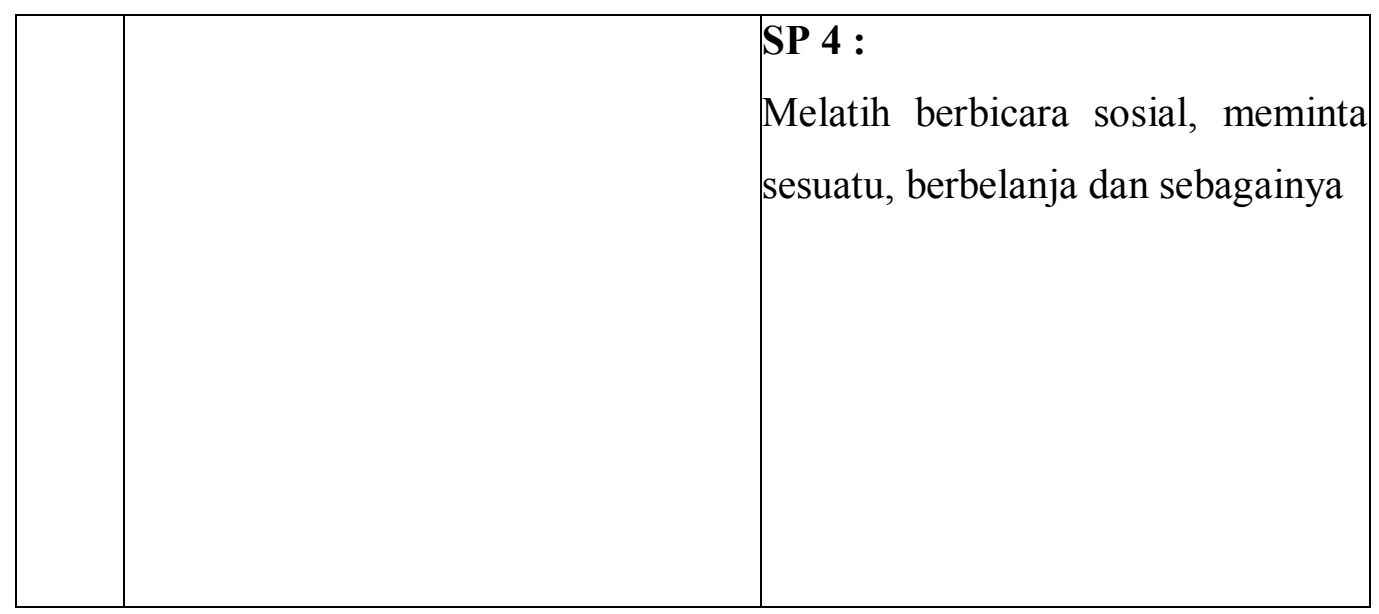

\subsection{Implementasi dan Evaluasi}

\begin{tabular}{|c|c|c|}
\hline Hari/tgl & Implementasi & Evaluasi \\
\hline $\begin{array}{l}\text { Jumat } \\
\text { 19/02/2021 } \\
\text { Pukul } \\
\text { 10:00 WIB }\end{array}$ & $\begin{array}{l}\text { 1.Data } \\
\text { Tanda dan gejala : mondar- } \\
\text { mandir, berbicara sendiri } \\
\text {,ngawur, sering senyum-senyum } \\
\text { sendiri, mendengar suara-suara } \\
\text { tanpa wajah, gelisah } \\
\text { 2.Diagnosa Keperawatan } \\
\text { Husinasi pendengaran } \\
\text { 3.Tindakan Keperawatan } \\
\text { Sp1: } \\
\text { - Melatih } \\
\text { mengenditifikasi halusinasi : } \\
\text { isi frekuensi, waktu terjadi, } \\
\text { suara,pencetus, perasaan dan } \\
\text { respon halusinasi } \\
\text { - Mengontrol halusinasi dengan } \\
\text { cara menghardik } \\
\text { Sp 2: } \\
\text { Mengontrol halusinasi } \\
\text { dengan cara minum obat secara }\end{array}$ & $\begin{array}{l}\text { S : Senang } \\
\text { O : Klien mampu mengenali } \\
\text { halusinasinya dengan mandiri } \\
\text { - Klien mampu menghardik } \\
\text { halusinasinya dengan } \\
\text { motivasi perawat. } \\
\text { - Klien mampu minum obat } \\
\text { dengan motivasi perawat. } \\
\text { - Klien mampu melakukan } \\
\text { latihan fisik tarik nafas } \\
\text { dalam dengan mandiri } \\
\text { - Klien mampu pukul kasur } \\
\text { bantal dengan mandiri } \\
\text { A : Halusinasi pendengaran }(+)\end{array}$ \\
\hline
\end{tabular}




\begin{tabular}{|c|c|c|}
\hline & $\begin{array}{l}\text { teratur } \\
\text { Sp } 3 \text { : } \\
\text { Mengontrol halusinasi } \\
\text { dengan bercakap-cakap } \\
\text { dengan orang lain } \\
\text { Sp } 4 \text { : } \\
\text { Mengontrol halusinasi } \\
\text { dengan melakukan kegiatan } \\
\text { terjadwal }\end{array}$ & \\
\hline $\begin{array}{l}\text { Sabtu } \\
\text { 20/02/2021 } \\
\text { Pukul } \\
\text { 12:00 WIB }\end{array}$ & $\begin{array}{l}\text { 1. Data } \\
\text { - } \text { Tanda dan gejala : mondar- } \\
\text { mandir, berbicara sendiri } \\
\text {,ngawur, sering senyum-senyum } \\
\text { sendiri, mendengar suara-suara } \\
\text { tanpa wajah, gelisah } \\
\text { 2. Diagnosa Keperawatan } \\
\text { Gangguan sensori persepsi : } \\
\text { halusinasi pendengaran } \\
\text { 3. Intervensi Keperawatan } \\
\text { SP } 2 \\
\text { Latih cara minum obat dengan } \\
\text { prinsip } 6 \text { benar } \\
\text { 4. Implementasi Keperawatan } \\
\text { Melatih cara minum obat dengan } \\
\text { prinsip } 6 \text { benar } \\
\text { Rencana Tindak Lanjut : SP } 3 \\
\text { (mengendalikan } \\
\text { dengan bercakap-cakap dengan } \\
\text { orang lain) }\end{array}$ & $\begin{array}{l}\text { S : Klien Senang dan Antusias. } \\
\text { O : Klien mampu minum obat } 2 \\
\text { kali dalam sehari, klien mampu } \\
\text { mengontrol halusinasi dengan } \\
\text { minum obat secara teratur } \\
\text { dengan bantuan pengawas } \\
\text { yayasan } \\
\text { A : Halusinasi pendengaran } \\
\text { berkurang } \\
\mathbf{P}: \text { Intervensi tetap dilakukan } \\
\text { - Latihan menghardik } \\
\text { halusinasi } 3 \text { kali sehari } \\
\text { - Latihan minum obat } \\
\text { dengan prinsip } 6 \text { benar } 2 \\
\text { kali sehari }\end{array}$ \\
\hline $\begin{array}{l}\text { Senin } \\
22 / 02 / 2021 \\
\text { Pukul } \\
\text { 10:00 Wib }\end{array}$ & $\begin{array}{l}\text { 1. Data } \\
\text { - Klien mengatakan mendengar } \\
\text { suara-suara yang isinya "Haloo } \\
\text { kamu siapa" } \\
\text { - Klien mengatakan Suara-suara }\end{array}$ & $\begin{array}{l}\text { S : Klien mengatakan bahwa } \\
\text { suara-suara tersebut masih } \\
\text { datang, klien mengatakan dia } \\
\text { merasa senang bisa bercakap- } \\
\text { cakap dengan orang lain }\end{array}$ \\
\hline
\end{tabular}




\begin{tabular}{|c|c|c|}
\hline & $\begin{array}{l}\text { itu muncul waktu malam hari, } \\
\text { siang hari, dan saat ingin tidur. } \\
\text { - } \text { Klien tampak bicara-bicara } \\
\text { sendiri. Mulut klien tampak } \\
\text { komat-kamit. } \\
\text { 2. Diagnosa Keperawatan } \\
\text { Gangguan sensori persepsi : } \\
\text { halusinasi pendengaran } \\
\text { 3. Intervensi Keperawatan } \\
\text { SP } 3 \text { hatih mengendalikan halusinasi } \\
\text { dengan bercakap-cakap dengan } \\
\text { orang lain } \\
\text { 4. Implementasi Keperawatan } \\
\text { Melatih mengendalikan halusinasi } \\
\text { dengan bercakap-cakap } \\
\text { dengan orang lain } \\
\text { Rencana Tindak Lanjut : SP } 4 \\
\text { (Mengendalikan halusinasi dengan } \\
\text { dilakukan di yayasan) }\end{array}$ & 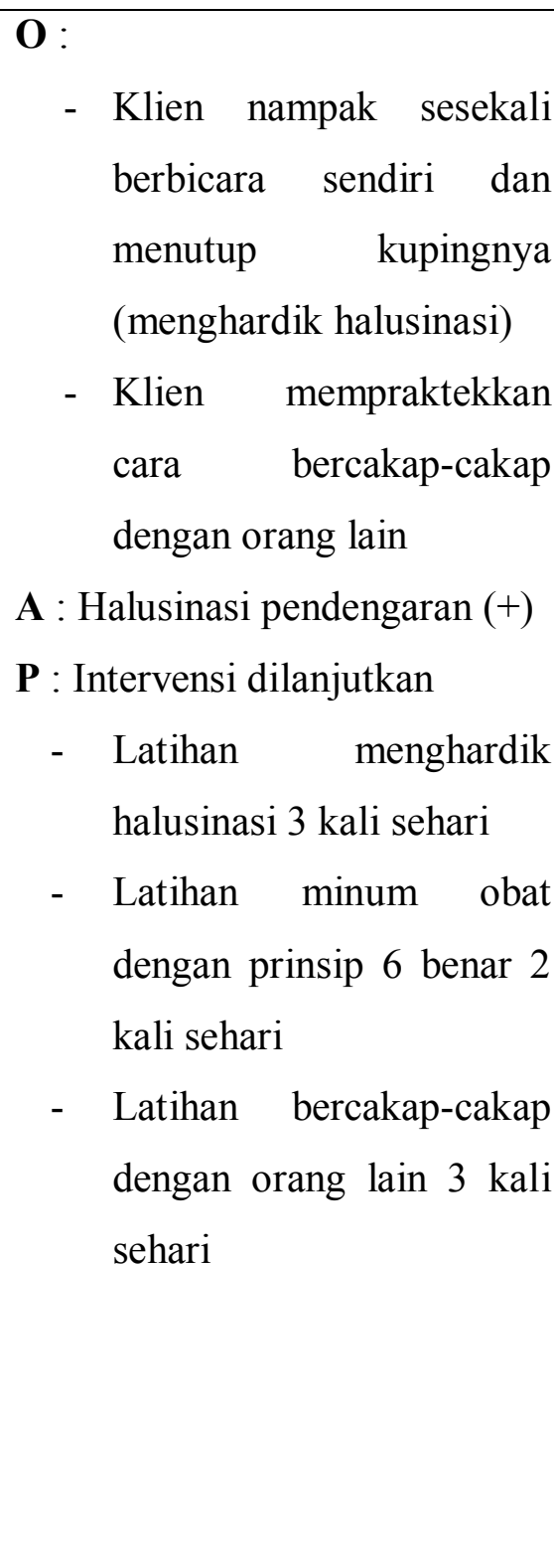 \\
\hline $\begin{array}{l}\text { Kamis } \\
\text { 24/02/2021 } \\
\text { Pukul } \\
\text { 10:00 Wib }\end{array}$ & $\begin{array}{l}\text { 1. Data } \\
\text { - Tanda dan gejala : mondar- } \\
\text { mandir, berbicara sendiri } \\
\text {,ngawur, sering senyum- } \\
\text { senyum sendiri, mendengar } \\
\text { suara-suara tanpa wajah, } \\
\text { gelisah. } \\
\text { 2. Diagnosa Keperawatan }\end{array}$ & $\begin{array}{l}\text { S : Klien mengatakan biasa } \\
\text { memasang seprei di kamarnya, } \\
\text { sesekali mau menyapu dan } \\
\text { mengepel kamarnya. } \\
\text { O : } \\
\text { - Klien mampu melakukan } \\
\text { kegiatan yang biasa } \\
\text { dilakukannya di Yayasan }\end{array}$ \\
\hline
\end{tabular}




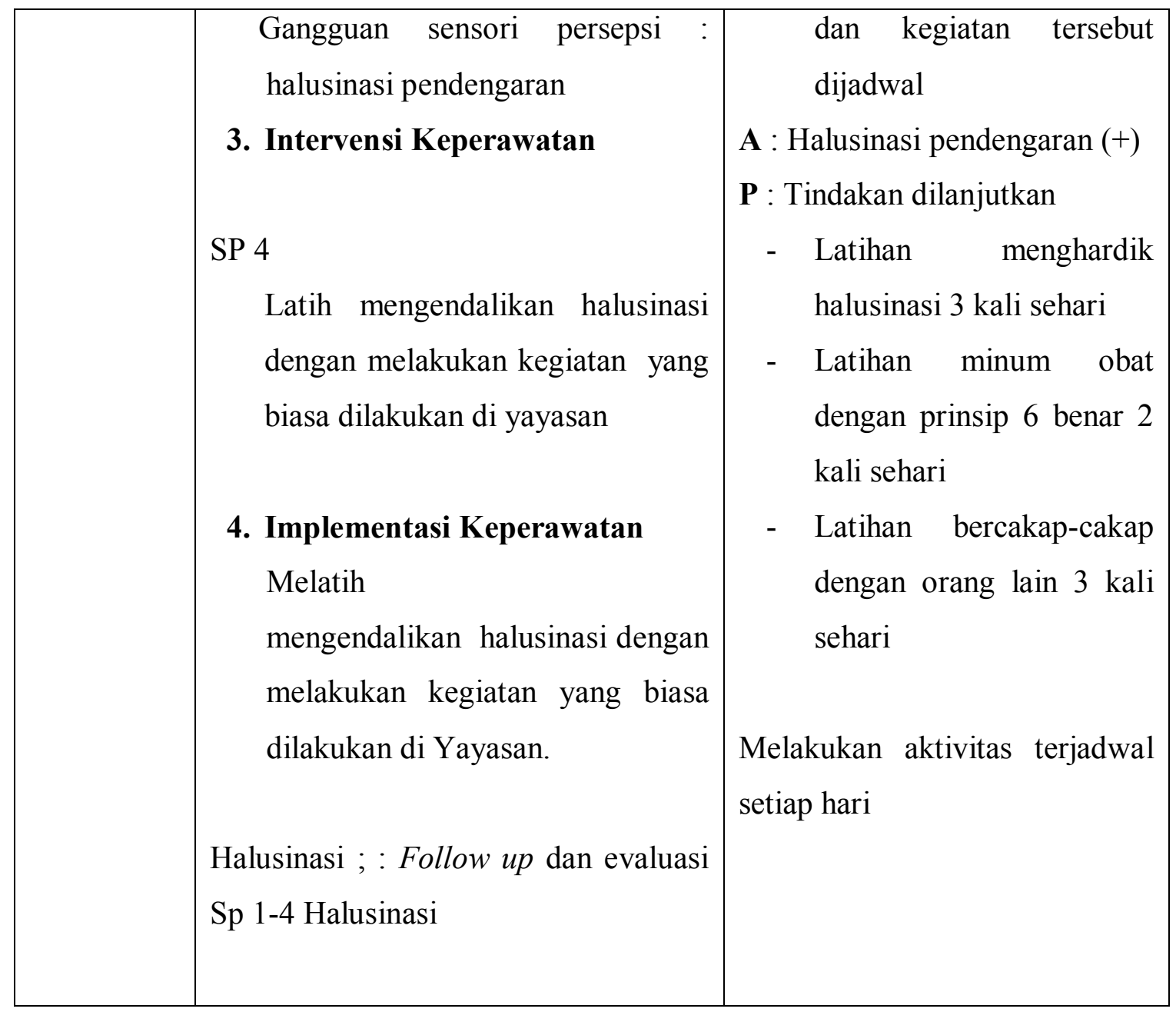




\section{BAB 4 \\ PEMBAHASAN}

Setelah penulis melaksanakan asuhan keperawatan kepada $\mathrm{Tn} \mathrm{T}$ dengan gangguan sensori persepsi: halusinasi pendengaran di Yayasan Pemenang Jiwa, maka penulis pada $\mathrm{BAB}$ ini akan membahas kesenjangan antara teoritis dengan tinjauan kasus. Pembahasan dimulai melalui tahapan proses keperawatan yaitu pengkajian, diagnosa keparawatan, perencanaan, pelaksanaan dan evaluasi.

\subsection{Pengkajian}

Pada pembahasan ini diuraikan tentang hasil pelaksanaan tindakan keperawatan dengan pemberian terapi generalis pada klien halusinasi pendengaran. Pembahasan menyangkut analisis hasil penerapan terapi generalis terhadap masalah keperawatan halusinasi pendengaran. Tindakan keperawatan didasarkan pada pengkajian dan diagnosis keperawatan yang terdiri dari tindakan generalis yang dijabarkan sebagai berikut.

Tahap pengkajian pada klien halusinasi dilakukan interaksi perawat-klien melalui komunikasi terapeutik untuk mengumpulkan data dan informasi tentang status kesehatan klien. Pada tahap ini terjadi proses interaksi manusia, komunikasi, transaksi dengan peran yang ada pada perawat sebagaimana konsep tentang manusia yang bisa dipengaruhi dengan adanya proses interpersonal.

Selama pengkajian dilakukan pengumpulan data dari beberapa sumber, yaitu dari pasien dan tenaga kesehatan di ruangan. Penulis mendapat sedikit kesulitan dalam menyimpulkan data karena keluarga pasien jarang mengunjungi pasien di rumah sakit jiwa. Maka penulis melakukan pendekatan kepada pasien melalui komunikasi terapeutik yang lebih terbuka membantu pasien untuk memecahkan perasaannya dan juga melakukan observasi kepada pasien.

Adapun upaya tersebut yaitu:

a. Melakukan pendekatan dan membina hubungan saling percaya diri pada klien agar klien lebih terbuka dan lebih percaya dengan menggunakan perasaan.

b. Mengadakan pengkajian klien dengan wawancara 
Dalam pengkajian ini, penulis menemukan kesenjangan karena ditemukan. Pada kasus Tn T klien mendengar suara-suara aneh, mondar-mandir, tampak tegang, putus asa, sedih dan lain-lain. Gejala gejala yang muncul tersebut tidak semua mencakup dengan yang ada di teori klinis dari halusnasi (Keliat, dkk.2014). Akan tetapi terdapat faktor predisposisi maupun presipitasi yang menyebabkan kekambuhan penyakit yang dialami oleh $\mathrm{Tn} \mathrm{T}$.

Tindakan keperawatan terapi generalis yang dilakukan pada Tn T adalah strategi pertemuan pertama sampai pertemuan empat. Strategi pertemuan pertama meliputi mengidentifikasi isi, frekuensi, jenis, dan respon klien terhadap halusinasi serta melatih cara menghardik halusinasi. Strategi pertemuan kedua yang dilakukan pada Tn T meliputi melatih cara mengendalikan dengan bercakapcakap kepada orang lain. Strategi pertemuan yang ketiga adalah menyusun jadwal kegiatan bersama-sama dengan klien. Strategi pertemuan keempat adalah mengajarkan dan melatih $\mathrm{Tn} \mathrm{T}$ cara minum obat yang teratur.

\subsection{Diagnosa Keperawatan}

Pada Teori Halusinasi (NANDA, 2009-2011), diagnosa keperawatan yang muncul sebanyak 3 diagnosa keperawatan yang meliputi:

1. Harga diri rendah

2. Halusinasi

3. Resiko Perilaku Kekerasan

Sedangkan pada kasus Tn $\mathrm{T}$ ditemukan diagnosa keperawatan yang muncul yang meliputi: Halusinasi pendengaran dan Perilaku Kekerasan. Dari hal tersebut di atas dapat dilihat terjadi kesamaan antara teori dan kasus. Dimana semua diagnosa pada teori muncul pada kasus Tn T

\subsection{Implementasi}

Pada tahap implementasi, penulis hanya mengatasi 2 masalah keperawatan yakni: diagnosa keperawatan halusinasi pendengaran dan Perilaku Kekerasan. Pada diagnosa keperawatan gangguan persepsi sensori halusinasi pendengaran 
dilakukan strategi pertemuan yaitu mengidentifikasi isi, frekuensi, waktu terjadi, perasaan, respon halusinasi. Kemudian strategi pertemuan yang dilakukan yaitu latihan mengontrol halusinasi dengan cara menghardik. Strategi pertemuan yang kedua yaitu anjurkan minum obat secara teratur, strategi pertemuan yang ke tiga yaitu latihan dengan cara bercakap-cakap pada saat aktivitas dan latihan strategi pertemuan ke empat yaitu melatih klien melakukan semua jadwal kegiatan (Pardede et al, 2021)

\subsection{Evaluasi}

Pada tinajauan teoritis evaluasi yang diharapkan adalah: Pasien mempercayai perawat sebagai terapis, pasien menyadari bahwa yang dialaminya tidak ada objeknya, dapat mengidentifikaasi halusinasi, dapat mengendalikan halusinasi melalui menghardik, latihan bercakap-cakap, melakukan aktivitas serta menggunakan obat secara teratur.

Pada tinjauan kasus evaluasi yang didapatkan adalah: Klien mampu mengontrol dan mengidentifikasi halusinasi, Klien mampu melakukan latihan bercakap-cakap dengan orang lain, Klien mampu melaksanakan jadwal yang telah dibuat bersama, Klien mampu memahami penggunaan obat yang benar:. Selain itu, dapat dilihat dari setiap evalusi yang dilakukan pada asuhan keperawatan, dimana terjadi penurunan gejala yang dialami oleh Tn T dari hari kehari selama proses interaksi. 


\section{BAB 5 \\ PENUTUP}

\subsection{Kesimpulan}

Berdasarkan uraian pada pembahasan di atas, maka penulis dapat disimpulkan bahwa:

1. Pengkajian dilakukan secara langsung pada klien dan juga dengan menjadikan status klien sebagai sumber informasi yang dapat mendukung data-data pengkajian. Selama proses pengkajian, perawat mengunakan komunikasi terapeutik serta membina hubungan saling percaya antara perawat-klien. Pada kasus Tn T diperoleh bahwa klien mengalami gejala-gejala halusinasi seperti mendengar suara-suara, gelisah, sulit tidur, tampak tegang, mondarmandir,tidak dapat mempertahankan kontak mata, sedih, malu, putus asa, menarik diri, mudah marah dan lain-lain. Faktor predisposisi pada Tn T yaitu pernah mengalami gangguan jiwa sebelumnya.

2. Diagnosa keperawatan yang muncul pada kasus Tn T Halusinasi pendengaran, isolasi sosial, koping individu inefektif, regimen teraupetik keluarga inefektif, harga diri rendah serta keputusasaan. Tetapi pada pelaksanaannya, penulis fokus pada masalah utama yaitu halusinasi pendengaran.

3. Perencanaan dan implementasi keperawatan disesuaikan dengan strategi pertemuan pada pasien halusinasi pendengaran dan isolasi sosial.

4. Evaluasi diperoleh bahwa terjadi peningkatan kemampuan klien dalam mengendalikan halusinasi yang dialami serta dampak pada penurunan gejala halusinasi pendengaran yang dialami.

\subsection{Saran}

1. Bagi Perawat

Diharapkan dapat menerapkan komunikasi terapeutik dalam pelaksanaan strategi pertemuan 1-3 pada klien dengan halusinasi sehingga dapat mempercepat proses pemulihan klien. 
2. Bagi Institusi Pendidikan

Dapat meningkatkan bimbingan praktek lapangan kepada mahasiswa profesi ners sehingga mahasiswa semakin mampu dalam melakukan asuhan keperawatan pada pasien-pasien yang mengalami halusinasi pendengaran.

3. Bagi Pasien

Laporan ini diharapkan dapat menjadi acuan dan referensi dalam memberikan asuhan keperawatan pada klien dengan halusinasi pendengaran. 


\section{DAFTAR PUSTAKA}

1. Anggraini, T \& Maula, (2021). Asuhan Keperawatan Jiwa pada An. S Dengan gangguan persepsi sensori halusinasi pendengaran. Karya tulis ilmiah,universitas kusuma husada Surakarta.

http://eprints.ukh.ac.id/id/eprint/1510/1/

2. Aji, W. M. H. (2019). Asuhan Keperawatan Orang Dengan Gangguan Jiwa Halusinasi Dengar Dalam Mengontrol Halusinasi. https://doi.org/10.31219/osf.io/n9dgs

3. Hernandi, B. (2020). Penerapan Aktivitas Terjadwal Pada Klien Dengan Gangguan Halusinasi Di Wilayah Kerja Puskesmas Godean 1 (Skrpsi dissertation, Poltekkes Kemenkes Yogyakarta). http://eprints.poltekkesjogja.ac.id/id/eprint/2581

4. Hafizuddin, D. T. M. (2021). Mental Nursing Care on Mr. A With Hearing Hallucination Problems. https://doi.org/10.31219/osf.io/r3pqu

5. Husein, A. N., \& Arifin, S. (2011) . Gambaran Distribusi Penderita Gangguan Jiwa Di Wilayah Banjarmasin Dan Banjarbaru. Berkala Kedokteran, 9(2), 199209. http://dx.doi.org/10.20527/jbk.v9i2.950

6. Keliat, B. A. (2011). Keperawatan Kesehatan Jiwa Komunitas. EGC, Jakarta

7. Keliat, B.A \& Akemat. (2014). Model Praktik Keperawatan Profesional Jiwa. Jakarta. EGC

8. Kemenkes RI. (2018). Riset Kesehatan Dasar; Riskesdas. Jakarta: Kemenkes RI https://databoks.katadata.co.id/datapublish/2019/10/08/persebaran-prevalensiskizofreniapsikosis-di-indonesia

9. Mubin, M. F \& P. H. Livana. (2019). Hubungan Kepatuhan Minum Obat Dengan Kekambuhan Pasien Skizofrenia Paranoid." Jurnal Farmasetis (8).1 https://doi.org/10.32583/farmasetis.v8i1.493

10. Nyumirah S (2013). Peningkatan kemampuan interaksi sosial kognitif,efektif,dan perilaku melalui penerapan terapi perilaku kognitif Di RSJD Dr. Amino Gondohutomo Semarang, Jurnal keperawatan jiwa. (1)2, November 2013 https://doi.org/10.26714/jkj.1.2.2013.\%25p

11. Oktiviani, D. P. (2020). Asuhan Keperawatan Jiwa Pada Tn. K dengan masalah Gangguan Persepsi Sensori: Halusinasi Pendengaran di Ruang Rokan Rumah Sakit Jiwa Tampan. Skripsi, Poltekkes Kemenkes Riau. http://repository.pkr.ac.id/id/eprint/498 
12. Pardede, J. A., Keliat, B. A., \& Wardani, I. Y. (2013). Pengaruh Acceptance And Commitment Therapy Dan Pendidikan Kesehatan Kepatuhan Minum Obat Terhadap Gejala, Kemampuan Berkomitmen Pada Pengobatan Dan Kepatuhan Pasien Skizofrenia. FIK UI. Depok

13. Pardede, J. A., Keliat, B. A., \& Yulia, I. (2015). Kepatuhan dan Komitmen Klien Skizofrenia Meningkat Setelah Diberikan Acceptance And Commitment Therapy dan Pendidikan Kesehatan Kepatuhan Minum Obat. Jurnal Keperawatan Indonesia,18(3),157-166.doi.org/10.7454/jki.v18i3.419

14. Pardede, J. (2020). Family Knowledge about Hallucination Related to Drinking Medication Adherence on Schizophrenia Patient. Jurnal Penelitian Perawat Profesional, 2(4), 399-408.https://doi.org/10.37287/jppp.v2i4.183

15. Pardede, J. A., \& Laia, B. (2020). Decreasing Symptoms of Risk of Violent Behavior in Schizophrenia Patients Through Group Activity Therapy. Jurnal Ilmu Keperawatan Jiwa, 3(3), 291-300. http://dx.doi.org/10.32584/jikj.v3i3.621

16. Pardede, J. A., Sirait, D., Riandi, R., Emanuel, P., \& Laia, R. (2016). Ekspresi Emosi Keluarga Dengan Frekuensi Kekambuhan Pasien Skizofrenia. Idea Nursing Journal, 7(3), 53-61. https://doi.org/10.52199/inj.v7i3.6446

17. Prabowo, E. (2014). Buku Ajar Keperawatan Jiwa. Yogyakarta: Nuha Medika.

18. Stuart, G. W. (2013). Buku Saku Keperawatan Jiwa . Edisi 5. Jakarta. EGC.

19. Utami, B. (2021). Penerapan Asuhan Keperawatan Jiwa Pada Tn. A Dengan Gangguan Sensori Persepsi: Halusinasi. doi:10.31219/osf.io/54sv3

20. Wicaksono, M. S., \& Arum Pratiwi, S. K. (2017). Teknik Distraksi Sebagai StrategiMenurunkan Kekambuhan Halusinasi (Doctoral dissertation, Universitas Muhammadiyah Surakarta). http://eprints.ums.ac.id/id/eprint/52316

21. Wulandari, N., Siyamti, D., \& Wulansari, W. (2020). Pengelolaan Halusinasi Perabaan Pada Ny. R Dengan Skizofrenia Di Wisma Arimbi Rumah Sakit Jiwa Prof. Dr. Soerojo Magelang. Universitas Ngudi Waluyo. http://repository2.unw.ac.id/id/eprint/1160

22. Yusuf, A. (2015). Buku Ajar Keperawatan Kesehatan Jiwa. Jakarta: Salemba Medika.

23. Zelika, A. A., \& Dermawan, D. (2015). Kajian Asuhan Keperawatan Jiwa Halusinasi Pendengaran Pada Sdr. D Di Ruang Nakula RSJD Surakarta. Profesi (Profesional Islam): Media

Penelitian, 12(02). https://doi.org/10.26576/profesi.87 